Obrazovanje odraslih, ISSN 1512-8784, Broj I - 202I., str. 6I-78

UDK: 374.7:339.138]:81'243(497.11)

DOI: $10.53617 /$ issn2744-2047.2021.21.1.61

Pregledni rad/Review paper

Primljeno/Received: 05. 04. $202 \mathrm{I}$.

Prihvaćeno/Accepted: 30. 08. 2021.

Jovan Miljković ${ }^{1}$

Marija Todorović ${ }^{2}$

\title{
Brendiranje škola stranog jezika kao organizatora neformalnog obrazovanja odraslih ${ }^{3}$
}

Sažetak: Kao cilj marketinga bilo koje organizacije, uključujući i obrazovnu, mogao bi se imenovati brend. Pitanje brenda u obrazovanju je sve aktuelnije, ali je dosadašnji fokus naučne zajednice ostao uglavnom na brendiranju visokog obrazovanja, dok su organizacije neformalnog obrazovanja odraslih po ovom pitanju uglavnom ignorisane. Stoga smo realizovali istraživanje sa ciljem da utvrdimo da li korisnici organizacija neformalnog obrazovanja doživljavaju pružaoca obrazovne usluge kao brend, kao i da identifikujemo koje aktivnosti sprovode organizacije neformalnog obrazovanja kako bi dosegle ovaj nivo povezanosti sa svojim korisnicima. U istraživanju je korišćena kombinacija kvantitativnokvalitativne istraživačke paradigme, sa multiplom studijom slučaja kao modelom istraživanja i deskriptivnom metodom kao dominantnom. Uzorak istraživanja čine menadžeri i polaznici analiziranih škola stranog jezika. Rezultati istraživanja ukazuju na to da i u Srbiji organizacije neformalnog obrazovanja prate svetske trendove i ulažu napore u dostizanju statusa obrazovnog brenda, ali i na to da brendiranje nije jednoobrazni proces, već da svaka organizacija i njihove strategije imaju određene specifičnosti.

Ključne reči: brend u obrazovanju, brendiranje, organizacije neformalnog obrazovanja, obrazovanje odraslih, škole stranih jezika.

\footnotetext{
${ }^{1}$ Dr Jovan Miljković, vanredni profesor na Filozofskom fakultetu Univerziteta u Beogradu, Odeljenje za pedagogiju i andragogiju; e-mail: jovan.miljkovic@f.bg.ac.rs

2 Marija Todorović, MA, menadžerka ljudskih resursa u kompaniji Bakson LTD; e-mail: marija.todorovic90@yahoo.com

${ }^{3}$ Rad je nastao u okviru projekta „Modeli procenjivanja i strategije unapređivanja kvaliteta obrazovanja u Srbiji“ (broj: 179060), koji finansira Ministarstvo prosvete, nauke i tehnološkog razvoja Republike Srbije.
} 


\section{Uvod}

Istraživanje je podstaknuto pitanjem da li je koncept brenda zaživeo među organizatorima neformalnog obrazovanja u Srbiji i na koji način se ove organizacije pozicioniraju prema fenomenu brendiranja. Jasno je da neke organizacije neformalnog obrazovanja odraslih imaju svoj brend, ali je nužno ispitati kako je taj brend stvoren i od čega zavisi strategija njegovog kreiranja, kao i da li ih i u kojoj meri polaznici percipiraju kao brend.

Ovo postaju ključna andragoška pitanja, jer je neformalno obrazovanje izbor velikog broja ljudi i njihov dominantni obrazovni put u procesu celoživotnog obrazovanja i učenja. Ne smemo se odati utisku da je neformalno obrazovanje i dalje prepušteno sebi, da se stihijski, kroz sistem pokušaja i pogrešaka, snalazi na tržištu. Važno je proučiti kako organizacije neformalnog obrazovanja komuniciraju sa polaznicima, privlače ih i vezuju za sebe. Samo ispitivanjem tržišta i proučavanjem akcija i planova obrazovne organizacije, ali i percepcije korisnika obrazovnih usluga, može se odgovoriti na izazove i dileme koje brendiranje obrazovanja nosi sa sobom.

\section{Teorijski okvir istraživanja}

Od svog nastanka brendiranje je simbol porekla, kvaliteta i statusa. Brend omogućava korisnicima da zadovolje potrebe i želje: od garancije stepena kvaliteta i potvrde porekla kupljenog proizvoda/usluge, preko poistovećivanja brenda sa poželjnim idealima i ličnim karakteristikama do zadovoljavanja potrebe za pripadnošću i samopotvrđivanjem.

Autori (Aaker 1991, Aaker 1997, Aaker 1999, Veljković 2010, Rakita i Mitić 2010, Keller i Kotler 2016) dali su definicije brenda u kojima se naglašava vrednost i emocionalna veza koju brendirani proizvod ima za korisnike, kao i visok stepen njihove identifikacije sa brendom i vrednostima koje taj brend propagira. Brend možemo definisati kao proizvod, uslugu, osobu ili mesto sa kojima se potrošači mogu identifikovati i koji sa sobom nose relevantne, jedinstvene dodatne vrednosti koje zadovoljavaju potrebe korisnika, a ujedno izazivaju $i$ emocije koje se vezuju za taj brend. Najopštije rečeno, brend predstavlja percepciju korisnika o određenom proizvodu/usluzi, koja ima dodatnu vrednost za potrošača. 
Postoje različite karakteristike brenda, od kojih su nam najprihvatljivije one koje su izdvojili Veljković i Đorđević (2010): identitet (brand identity), prepoznatljivost (brand awareness), vrednost (brand equity), lojalnost ili posvećenost brendu (brand loyalty).

Identitet brenda (identity) je diferenciranje organizacije i proizvoda/usluga od ostalih koje postoje na tržištu, kroz vizuelne karakteristike brenda, misije, vizije i propagirane vrednosti.

Suština prepoznatljivosti (awareness) brenda je „da su potrošači svesni njegovih karakteristika i vrednosti” (Veljković i Đorđević 2010: 6), što se postiže u okviru ciljne grupe, kroz prilagođavanje reklamne kampanje i kanala komunikacije ciljnoj grupi.

Brendovi povećavaju svoju vrednost (equity) tako što za korisnike predstavljaju garanciju kvaliteta i sigurnosti, što se prema Veljkoviću i Đorđeviću (2010) najefikasnije postiže stavljanjem fokusa na emotivne i iskustvene asocijacije korisnika, u kojima su proizvod/usluga garancija očekivanog kvaliteta, pripadnosti supkulturi i pokazatelj posedovanja određenih karakteristika (ličnosti) korisnika. Ovo bi u slučaju organizacije obrazovanja odraslih mogla da bude i dominantna karakteristika, jer obrazovanje „ne nudi samo proizvod ili uslugu, već mnogo više, znanje i umenje, način mišljenja, a time stil i način života“ (Alibabić 2002: 62), odnosno ono što autori (Miljković 2010: 210) nazivaju „dodatnom vrednošću“.

Lojalnost brendu (loyalty) je verovatnoća da će korisnici u budućnosti koristiti određeni brend, bez obzira na promene tržišnih okolnosti i konkurenciju koja nudi isti tip proizvoda (Veljković i Đorđević 2010). Kako bismo prilikom definisanja termina „lojalnosti brendu“ zahvatili veći spektar osećanja koje jedan brend budi u svojim korisnicima (a anglosaksonska literatura podrazumeva), iskoristili smo trokomponentnu teoriju posvećenosti koju je predložila Ovesni (2014: 157), a koja navodi „posvećenost“ kao pojavu koja u sebi sadrži lojalnost, ali i privrženost i zahvalnost.

Brendiranje je „proces izgradnje svesnosti kod potrošača o postojanju brenda i izgradnje njihove lojalnosti brendu“ (Rakita i Mitić 2010: 77). Brend motiviše, poziva na akciju, izaziva emocije, evocira uspomene i gradi poverenje. Pretpostavljamo da je cilj svake organizacije da kreira prepoznatljiv brend pomoću kog će da upravlja vezom između korisnika i usluge. 


\section{Brend u obrazovanju}

Brend u obrazovanju je uticajan jer ima moć da kroz obrazovanje dublje utiče na društvo i individuu. Pored nekoliko istraživanja marketinških strategija i (opšteg) brenda, u stranoj i domaćoj literaturi uviđa se nedostatak istraživanja koja se bave strategijama i akcijama kreiranja brenda organizacija neformalnog obrazovanja, pa smo se zato fokusirali na ovu oblast.

Najvažniji ciljevi brendiranja u kontekstu obrazovanja su privlačenje polaznika, njihovo zadržavanje i formiranje veze sa brendom škole, što se postiže odgovaranjem na potrebe polaznika i obezbeđivanjem ukupnog kvaliteta obrazovne usluge. Brend u obrazovanju možemo posmatrati kao prepoznatljivost organizacije, vrednost znanja i garanciju kvaliteta koji određena obrazovna organizacija poseduje. Sa druge strane, privlačan brend obrazovne organizacije uzrokuje emotivnu povezanost, pripadnost i sliku koju učenici grade o sebi samim tim što pohađaju neku određenu školu.

Kako bi tržišne organizacije bile sposobne da izađu u susret zahtevima poslovne sredine koja se konstantno menja, moraju i same da se menjaju u skladu sa sredinom (Đorđević-Boljanović 2010). Mišljenja smo da su agilnost, prilagodljivost i brzo odgovaranje na promene sredine bitne osobine konkurentnih i kvalitetnih obrazovnih organizacija.

\section{Metodološki okvir istraživanja}

Kao model istraživanja koristili smo multiplu studiju slučaja (menadžere i polaznike tri organizacije neformalnog obrazovanja) u okviru koje je kombinovana kvantitativna i kvalitativna istraživačka paradigma. Cilj istraživanja je utvrđivanje karakteristika brendova organizacija neformalnog obrazovanja, kao i načina na koji su kreirani. Cilj smo operacionalizovali kroz tri zadatka. Prvim zadatkom smo želeli da saznamo da li postoji veza između aktivnosti brendiranja organizacija neformalnog obrazovanja i nekih njenih kontingencijskih faktora. Drugi zadatak istraživanja je utvrđivanje i opis aktivnosti organizacija neformalnog obrazovanja koje su usmerene na kreiranje brenda, dok u trećem zadatku pokušavamo da utvrdimo da li polaznici organizacija neformalnog obrazovanja smatraju da je škola koju pohađaju dosegla status brenda. 
Kvantitativnu istraživačku paradigmu smo koristili u trećem zadatku u okviru koga smo utvrdili percepciju korisnika obrazovne usluge o pružaocu usluge kao obrazovnom brendu, operacionalizovanu preko percepcije polaznika o razvijenosti elemenata brenda obrazovne organizacije koju pohađaju: identitet organizacije, njena prepoznatljivost, vrednost i lojalnost koju joj iskazuju polaznici. Koristili smo deskriptivnu metodu, a u okviru nje anketiranje i skaliranje. Instrument je sačinjavala baterija instrumenta sastavljena od ankete i skale likertovog tipa, sa 50 ajtema, a relijabilnost instrumenta je visoka sa skorom od .952 Crombach's Alpha. Uzorak je prigodan i obuhvata 68 ispitanika iz tri beogradske škole stranog jezika: škola „E“ (24 ispitanika), škola „B“ (22 ispitanika) i škola „I“ (22 ispitanika).

Kvalitativnu paradigmu smo primenili u okviru prva dva zadatka istraživanja. Imali smo dve kompleksne jedinice posmatranja: kontingencijske faktore analiziranih organizacija i aktivnosti brendiranja organizacija neformalnog obrazovanja. I ovde smo koristili deskriptivnu metodu, a u okviru nje intervjuisanje i analizu sadržaja dokumentacije. Kao instrumenti, korišćeni su polustrukturirani intervju kojim smo intervjuisali po jednog menadžera iz svake od obrazovnih organizacija, a za analizu sadržaja dokumentacije koristili smo protokol. Polustrukturirani intervju se sastojao od 21 otvorenog pitanja kojima smo ispitivali kontingencijske karakteristike obrazovne organizacije, viziju pojedinačnih elementa brenda obrazovne organizacije i akcije koje su usmerene na njihovo građenje.

\section{Analiza i interpretacija rezultata istraživanja}

Povezanost izmedu aktivnosti brendiranja organizacija neformalnog obrazovanja i nekih njihovih kontingencijskih faktora

Istraživanjem smo ispitali vezu između aktivnosti brendiranja organizacija neformalnog obrazovanja i kontingencijskih faktora, ali nažalost, većinu kontingencijskih faktora ispitivane organizacije smatraju poslovnom tajnom, pa smo se morali zadovoljiti tehnologijom, veličinom i starošću.

Škola „E“ je najmlađa od analiziranih organizacija - osnovana je 2000. godine u Beogradu, a posle dve decenije rada nalazi se na 11 lokacija u gradu. 
Tehnički uslovi za rad su optimalni, u šta smo se posetom i uverili. Tehnologija pružanja obrazovnih usluga se zasniva na pristupu „licem u lice“. Smatraju da imaju jedinstven didaktički pristup, jer koriste interaktivne metode poučavanja. Čini nam se da je relativna mladost organizacije omogućila da se prilagođavaju tržištu, koristeći savremene načine oglašavanja, praćenja interesovanja polaznika i prepoznavanja potreba tržišta, ali i da u svoju organizacionu strukturu uvrste marketinški sektor, koji se mnogo lakše uvodi prilikom osnivanja institucije, nego tokom njenog kasnijeg poslovanja (Miljković 2009). Zbog svoje mladosti, škola može da redizajnira i modernizuje svoje logotipe i boje prateći modne trendove na tržištu. Prednost mlade organizacije je što nije "okoštala" u svojoj tradiciji, tako da je "E" koristio taj potencijal kroz svoju ponudu, istražujući potrebe korisnika i nudeći im odgovarajuće kurseve. Sa druge strane, relativna mladost mogla je da dovede do upitnog kvaliteta ili nepoverenja korisnika u školu. To je predupređeno sistemom koji osigurava standardizaciju kvaliteta nastave, kao i usavršavanjem profesora, a lojalnost korisnika pokušavaju da dostignu i posebnim pogodnostima koje im nude.

Škola „B“ je franšiza škole osnovane 1878. godine u SAD-u, sa trenutno 550 lokacija u svetu. Prva škola ovoga lanca u Beogradu je otvorena 1914. godine, a trenutno u njemu posluje na četiri lokacije. Tehnički uslovi za rad su solidni, a tehnologija pružanja obrazovnih usluga je „licem u lice“. I ova škola tvrdi da radi po jedinstvenoj metodici, konverzacijom na ciljnom jeziku, bez prevođenja, sa instruktorima koji su maternji govornici. Od sve tri analizirane škole samo ova baštini globalni brend, marketinšku strategiju, većinu akcija i ima malo prostora za prilagođavanje lokalnom tržištu. Starost, odnosno tradicija, diktira i identitet, ali i metodiku rada. Organizacija garantuje kvalitet na svakoj svojoj lokaciji i to što je sertifikat škole "B" poznat i van naše zemlje, daje dobru osnovu za razvijanje reklamnih kampanja. Visoka cena usluge (viša u odnosu na druge dve škole) i mali broj lokacija doprinose osećaju ekskluzivnosti polaznika. Možemo konstatovati da škola "B" gradi brend preuzimajući vizuelni identitet i prepoznatljivost globalnog brenda, obećavajući polaznicima svetski poznat kvalitet i sertifikat globalne vrednosti.

Škola „I“ spada u škole sa dugom tradicijom (osnovana je 1952. godine), a pohađalo ju je preko 550.000 polaznika i izdala je 670 naslova u ukupnom tiražu od oko 1.000 .000 primeraka. Trenutno se nalazi na preko 20 lokacija u Beogradu 
(24 lokacije na kojima održava nastavu za decu i 6 lokacija za odrasle), a tehnologija rada („licem u lice“) standardizovana je u toj meri da je škola „I“ ovlašćeni centar za polaganje međunarodno priznatih ispita TOEFL iBT, TOEIC, PMI. Kao velika organizacija sa dugom tradicijom, razvila je prepoznatljivost među ciljnom grupom i očekivanja po pitanju nastave, profesora i vrednosti, ali prema našem mišljenju, struktura organizacije je okoštala i nasleđena iz ranijeg perioda, sa prosečnom opremljenošću učionica (što smo utvrdili prilikom obilaska škole) i pristupačnom cenom kurseva. Zaključke o okoštaloj organizacionoj strukturi izvodimo iz činjenice da funkcija marketinga nije organizaciono izdvojena, već se jedan deo profesora bavi njime. Institucija pokušava da zadrži brend kreiran u prošlosti, bez želje da ga menja i redizajnira. Osavremenjavanje brenda i upravljanje njegovom promenom definitivno su izazovi sa kojima će se škola "I" susresti u budućnosti.

\section{Aktivnosti organizacija neformalnog obrazovanja koje su usmerene na kreiranje brenda}

Što se tiče identiteta, škola "E" je razvila logo, dominantne boje i karakterističan font, koji osmišljavaju i redizajniraju na 4-5 godina i prilagođavaju trendovima. U misiji, viziji i vrednostima, škola naglašava društvene vrednosti, uvažava savremene trendove, a apostrofira intelektualni i socijalni razvoj polaznika. Ono što doprinosi kreiranju identiteta škole "E" je razvijen marketinški sektor, usmeren na analizu snaga i slabosti škole, praćenje efekata promotivnih kampanja i pozicije brenda. Menadžer škole naglašava da je analitika najvažnija u marketinškom sektoru, jer otkriva prostor za poboljšanje. Škola nije forsirala jednu ciljnu grupu, već imaju ponudu za sve uzraste, koji su podjednako zastupljeni u marketinškim kampanjama. Nastavnici su članovi profesionalnih udruženja, kreiraju ponude i programe u skladu sa potrebama polaznika. Ostvarujući prepoznatljivost škole, marketinško odeljenje vrši istraživanja anketiranjem polaznika, a koriste i $\mathrm{SEO}^{41}$ istraživanja, uz targetirane kampanje na internetu, nove internet alate i merenje posećenosti sajtova. U izboru reklamnih kanala preferiraju internet, društvene mreže, zakup internet

\footnotetext{
${ }^{4}$ Search Engine Optimization jeste proces dizajniranja, pisanja, kodiranja, programiranja i skriptovanja internet sajta u cilju boljeg rangiranja na pretraživačima, a može da meri i posećenost sajta.
} 
domena, u odnosu na tradicionalno reklamiranje uz pomoć flajera, oglasa i sl. Kvalitet obrazovnih usluga je dominantna vrednost na koju se škola "E” oslanja i koju sistematski razvija kroz istraživanje zadovoljstva polaznika, nenajavljene posete supervizora časovima, stručno usavršavanje zaposlenih. Nastavnici su osnovni nosioci vrednosti škole, koje manifestuju kroz svoj afirmativan pristup, komunikaciju i kompetentnost. Sve aktivnosti su usmerene na kvalitet obrazovne ponude, što treba da stvori i lojalnost kod polaznika. Postoje i akcije nagrađivanja lojalnosti korisnika: loyalty i studentske benefit kartice. Škola sistematski vrši istraživanja lojalnosti polaznika anketiranjem.

Škola „B“ je franšiza lanaca škola za strane jezike iz SAD-a, i identitet u potpunosti kreira i crpi iz svoje matične kuće. Logo, font, boje i misija su uniformni i omogućavaju prepoznatljivost na globalnom nivou. Odgovornost lokalnog menadžmenta je da prilagodi i implementira strategije koje se donose na globalnom nivou, a za tu potrebu se angažuju i eksterni stručnjaci. Škola nije usmerena na usku ciljnu grupu, jer nudi kurseve za više kategorija, što je analizom dokumentacije i potvrđeno. Identitet grade na metodu nastave koja je na ciljanom jeziku, bez prevođenja na maternji, grupe su male i učenje se bazira na realnim životnim situacijama i konverzaciji. Na kvalitet nastavnika se obraća posebna pažnja: svi su visoko kvalifikovani, izvorni govornici, svi prolaze posebnu didaktičku obuku, a njihov rad se periodično proverava. Da li je ostvarila prepoznatljivost škola „B“ proverava anketiranjem polaznika. Kako bi bili prepoznatljivi koriste oglašavanje na internetu i društvenim mrežama, ali i štampane medije zbog starijih generacija. I u ovoj školi, profesori su nosioci vrednosti škole. Menadžer škole „B“ u metodici rada i malim grupama vidi posebnu vrednost, a kvalitetu doprinosi i periodično istraživanje mišljenja korisnika usluga. Lojalnost škola „B“ ostvaruje kroz kvalitet usluge, dobre rezultate obrazovnog procesa, samopouzdanje koje njihovi učenici steknu uz pomoć kurseva, a postoje i popusti prilikom ponovnog upisa. Za utvrđivanje lojalnosti škola koristi anketiranje.

Škola „““ ima jasan vizuelni identitet koji nije menjala, a u misiji se naglašava status škole kao lidera, koji se dostiže korišćenjem metoda nastave koje je sama razvila, ali i vlastitom izdavačkom delatnošću i kreiranjem audio-vizuelnih pomagala u nastavi. Ciljne grupe škole su različite. U kampanjama koriste digitalne medije, ali i promotivne aktivnosti koje organizuju po univerzitetima, školama, korporacijama. Nosilac identiteta škole je nastavno osoblje koje čine isključivo 
diplomirani filolozi, a na tržištu ih ističu i akreditacije za polaganje TOEFL iBT, TOEIC, PMI ispita. Za istraživanje prepoznatljivosti na tržištu obrazovanja škola koristi ankete, a prema rečima menadžera koriste „apsolutno sve medije“ i prilagođavaju reklamne kampanje ciljnim grupama i njihovim kanalima. U istraživanjima koriste i SEO što je, pored anketa učenika, najprecizniji način da provere uspešnost kampanja i broj poseta svom sajtu. Istraživanja škole su usmerena i na kvalitet obrazovne usluge, koji smatraju nosiocem osnovnih vrednosti škole. Pored bavljenja sobom, škola istraživanjima utvrđuje novosti na tržištu, posebno proučavajući aktivnosti konkurencije. Škola „I” veoma vrednuje lojalnost i posvećenost svojih polaznika, koje pokušava da ostvari preko kvaliteta nastavnog kadra. Lojalnost pokušava da ostvari i uz pomoć popusta koji daje prilikom ponovnog upisa, ali pri tome treba imati u vidu procenu polaznika da kvalitet dobijene usluge ne opravdava visinu školarine ove organizacije.

Percepcija korisnika obrazovne usluge o pružaocu usluge kao obrazovnom brendu

Uz pomoć aritmetičke sredine procene četiri indikatora brenda (identiteta, prepoznatljivosti, vrednosti i lojalnosti) i frekvencije odgovora polaznika, dobijamo procenu svake od analiziranih obrazovnih organizacija kao o eventualnom obrazovnom brendu. Da li među školama stranog jezika u Srbiji postoje obrazovni brendovi, i kakve su karakteristike pojedinih indikatora potencijalnih obrazovnih brendova analiziranih škola, prikazaćemo u redovima koji slede.

Percepcija korisnika obrazovne usluge o školi „E“ kao obrazovnom brendu. Većina ispitanika smatra da škola "E" poseduje karakteristike brenda (Tabela broj 1).

Tabela broj 1: Procena karakteristika brenda škole „E“

\begin{tabular}{l|c|c}
\hline Karakteristike brenda škole „E“ & $\begin{array}{c}\text { Frekvencije potvrdnih } \\
\text { odgovora }\end{array}$ & Procenat \\
\hline Škola „E“ je prepoznatljiva na tržištu. & 19 & 79.1 \\
Škola „E“ ima razvijen identitet. & 17 & 70.8 \\
Polaznici škole „E“ su joj lojalni. & 17 & 70.8 \\
Škola „E“ nudi posebne vrednosti. & 16 & 66.7 \\
\hline
\end{tabular}


Od karakteristika najlošije je procenjena vrednost školovanja u ovoj organizaciji. Od indikatora vrednosti škole „Е“, najveću aritmetičku sredinu dobili su njeni nastavnici kao nosioci vrednosti (4.17), dok je najmanji skor dobila cena školovanja (2.87), kao reprezent vrednosti kurseva. Ukupna aritmetička sredina vrednosti škole jezika "E” je 3.61 što znači da, iako ispitanici smatraju da postoje vrednosti koju donosi školovanje u njoj, i dalje postoji značajan prostor za poboljšanje.

$\mathrm{Na}$ drugom i trećem mestu procene ispitanika su razvijenost lojalnosti polaznika škole i njen identitet. Što se tiče identiteta škole „E“, najizraženiji indikator je bio vizuelni identitet organizacije (AS: 4.04), dok je najlošije procenjeno značajno razlikovanje ove organizacije od drugih (AS: 3.29). Aritmetička sredina mišljenja ispitanika o postojanju identiteta škole „E“ je 3.7, što je dovoljno za konstataciju o postojanju ove karakteristike brenda.

Kada govorimo o lojalnosti korisnika usluge školi „E“, nju smo istraživali preko 16 pitanja, čija AS iznosi 3.8. Indikator iz ove grupe, koji je imao najvišu aritmetičku sredinu jeste lojalnost školi jer je ona uigran sistem (4.2), a najmanji skor je dobila vrednost sertifikata škole kao razloga lojalnosti (3.41). Ovi podaci su od značaja za obrazovnu organizaciju, jer korisnici koji imaju privrženost nekom brendu ponovo biraju isti i preferiraju "svoj brend" naspram drugih ponuđenih.

Najviše ispitanika iz škole "E” je navelo prepoznatljivost na tržištu kao njenu najizraženiju karakteristiku (AS: 3.73). Prepoznatljivost brenda je bitna jer izdvaja školu od konkurencije. Najviše skorove od indikatora ove karakteristike je dobila poznatost među širom javnošću (4.37), a najniže škola „E“ kao prvi izbor prilikom odabira škole jezika (3.33).

$\mathrm{Na}$ kraju, možemo konstatovati da korisnici obrazovne usluge percipiraju školu "E" kao brend, jer je skor aritmetičke sredine 3.73, u mogućem rasponu od 1 do 5. Distribucija odgovora ispitanika o školi „E“ kao brendu prikazana je u Tabeli br. 2. 
Tabela broj 2: Frekvencija odgovora ispitanika o

školi „E“ kao obrazovnom brendu

\begin{tabular}{l|c|c}
\hline & $\begin{array}{c}\text { Frekvencije } \\
\text { odgovora }\end{array}$ & Procenat \\
\hline Uopšte ne smatram školu „E“ za obrazovni brend & 1 & 4.2 \\
Ne smatram školu „E“ za obrazovni brend & 1 & 4.2 \\
Neodlučan/a sam da li je škola „E“ obrazovni brend & 3 & 12.5 \\
Smatram školu „E“ za obrazovni brend & 11 & 45.8 \\
U potpunosti smatram školu „E“ za brend & 8 & 33.3 \\
\hline & 24 & 100 \\
\hline
\end{tabular}

Percepcija korisnika obrazovne usluge o školi „B“ kao obrazovnom brendu. U slučaju škole „B“, 22 polaznika je procenjivalo da li su u ovoj školi prisutne sve karakteristike brenda, a odgovore smo predstavili u Tabeli broj 3 .

Tabela broj 3: Procena karakteristika brenda škole „B“

\begin{tabular}{l|c|c}
\hline Karakteristike brenda škole „B“ & $\begin{array}{c}\text { Frekvencije potvrdnih } \\
\text { odgovora }\end{array}$ & Procenat \\
\hline Škola „B“ ima razvijen identitet. & 21 & 95.5 \\
Polaznici škole „B“ su joj lojalni. & 21 & 95.5 \\
Škola „B“ je prepoznatljiva na tržištu. & 19 & 86.4 \\
Škola „B“ nudi posebne vrednosti. & 17 & 77.3 \\
\hline
\end{tabular}

Od karakteristika brenda najlošije je procenjena vrednost koju školovanje u ovoj organizaciji donosi. Od indikatora vrednosti škole „B“, najveću aritmetičku sredinu dobili su njeni nastavnici kao nosioci vrednosti (4.63), kao i trud škole da održi kvalitet nastave (4.63), dok je najmanji skor dobila cena kursa kao reprezent vrednosti škole (2.59). Aritmetička sredina vrednosti škole jezika "B” je 3.99 što znači da ispitanici smatraju da ona postoji.

Što se tiče identiteta škole "B”, polaznici su sigurni da škola poseduje ovu karakteristiku, o čemu govori ocena (4.57). Svi indikatori identiteta su dobili visoke ocene. Najviši skorovi su kod pitanja o jasno definisanim i komuniciranim ciljevima (4.72) i vizuelnom identitetu (4.68), dok je najmanji skor (mada i dalje vrlo visok: 4.36) dobila tvrdnja da se škola „B“ jasno razlikuje od sličnih na tržištu. 
Prepoznatljivost podrazumeva jasno definisanu ciljnu grupu i marketinške aktivnosti prilagođene njoj. Rezultat aktivnosti je brend kao prva asocijacija kada se kod ciljne grupe javi potreba za sferom delatnosti brenda, kao i svest korisnika da je taj brend prilagođen njima. Prema proceni polaznika, škola „B“ je uspela da razvije prepoznatljivost (aritmetička sredina je 4.00). Ipak, da i tu postoji prostor za napredak, kazuje procena sa najmanjim skorom u odnosu na ostale - prisutnost u medijima (3.45), dok je najviši skor dobio ajtem poznatost škole široj javnosti (4.63).

Lojalnost polaznika školi "B" je vrlo razvijena (AS: 4.33). Najmanji skor su dobili socijalni kontakti kao razlog lojalnosti (3.59), a najviši su rezervisani za školu kao uigran sistem (4.68), poverenje između nastavnika i polaznika (4.68) i tvrdnju da bi ponovo upisali ovu školu (4.72).

Na osnovu aritmetičke sredine, možemo konstatovati da korisnici obrazovne usluge škole „B“ percipiraju ovu školu kao brend, jer je skor 4.20, u mogućem rasponu od 1 do 5. Percepcija distribucije odgovora ispitanika o školi „B“ kao brendu prikazana je u Tabeli broj 4 .

Tabela broj 4: Frekvencija odgovora ispitanika o školi „B“ kao obrazovnom brendu

\begin{tabular}{l|c|c}
\hline & $\begin{array}{c}\text { Frekvencije } \\
\text { odgovora }\end{array}$ & Procenat \\
\hline Neodlučan/a sam da li je škola „B“ obrazovni brend & 1 & 4.5 \\
Smatram školu „B“ za obrazovni brend & 10 & 45.5 \\
U potpunosti smatram školu „B“ za brend & 11 & 50 \\
\hline
\end{tabular}

Percepcija korisnika obrazovne usluge o školi „I" kao obrazovnom brendu. Istraživanje je pokazalo (Tabela broj 5) da najviše polaznika smatra da škola ima lojalnost korisnika svojih usluga, a da su joj najmanje izražene posebne vrednosti. 
Tabela broj 5: Procena karakteristika brenda škole „I“

\begin{tabular}{l|c|c}
\hline \multicolumn{1}{c|}{ Karakteristike brenda škole „I“ } & $\begin{array}{c}\text { Frekvencije potvrdnih } \\
\text { odgovora }\end{array}$ & Procenat \\
\hline Polaznici škole „I“ su joj lojalni. & 18 & 81.9 \\
Škola „I“ ima razvijen identitet. & 16 & 72.7 \\
Škola „I“ je prepoznatljiva na tržǐštu. & 14 & 63.6 \\
Škola „I“ nudi posebne vrednosti. & 13 & 59.1 \\
\hline
\end{tabular}

Lojalnost školi "I” je od strane ispitanika procenjena sa srednjom ocenom 3.94. Socijalni kontakti su se pokazali kao najmanji razlog za lojanost (3.45), dok je poverenje između nastavnika i polaznika procenjeno sa najvećim skorom (4.31).

Što se tiče identiteta, aritmetička sredina odgovora je iznosila 3.95, što kazuje da polaznici smatraju da škola ima razvijenu ovu karakteristiku. Od indikatora identiteta škole, najniži skor je dobio vizuelni identitet škole (3.36), dok su najviši skorovi pripali vrednostima škole kao delu njenog identiteta, koje dele i njeni polaznici (4.45).

Prepoznatljivost obrazovne organizacije "I" postoji (AS: 3.63), a u okviru nje ispitanici su najlošije procenili kampanje koje škola sprovodi kako bi im privukla pažnju (AS: 2.45). Interesantno je da najviši skor imaju preporuke škole, koju su ispitanici dobili od bliskih im osoba (4.45).

Školovanje u školi "I” donosi polaznicima dodatne vrednosti (3.74), u okviru kojih je najlošije procenjena tvrdnja vezana za opravdanost visine školarine koja odgovara dobijenoj usluzi (2.63), dok su najveći skor dobili pouzdanost škole i kvalitet profesora (po 4.31).

Možemo konstatovati da polaznici škole „I“ percipiraju školu kao brend, jer je skor aritmetičke sredine 3.81, u mogućem rasponu od 1 do 5. Distribucija odgovora ispitanika o školi „I“ kao brendu prikazana je u Tabeli broj 6. 
Tabela broj 6: Frekvencija odgovora ispitanika o školi „I“ kao obrazovnom brendu

\begin{tabular}{l|c|c}
\hline & $\begin{array}{c}\text { Frekvencije } \\
\text { odgovora }\end{array}$ & Procenat \\
\hline Neodlučan/a sam da li je škola „“" obrazovni brend & 4 & 18.2 \\
Smatram školu „I“ za obrazovni brend & 13 & 59.1 \\
U potpunosti smatram školu „I“ za brend & 5 & 22.7 \\
\hline
\end{tabular}

Rezultati istraživanja pokazuju da se sve tri škole stranog jezika mogu smatrati obrazovnim brendom, na osnovu čega možemo zaključiti da se brendiranje koristi kao alat za optimizaciju pozicioniranja na tržištu obrazovanja odraslih. 


\section{Zaključak}

Rezultati ukazuju da je uloga kreatora brend-strategija da kombinuju kontingencijske faktore organizacije, karakteristike nastavnog kadra, prilike i izazove tržišta, kao i potrebe i želje korisnika, kako bi organizacije na najbolji način realizovale svoju misiju i viziju i bile konkurentne u oblasti svoga delovanja. Sve tri analizirane organizacije neformalnog obrazovanja odraslih mogu se smatrati obrazovnim brendom, a interesantno je da su sve tri uspele da se realizuju kao brend u vrlo širokoj populaciji, odnosno, ciljne grupe su im vrlo diverzifikovane. To su uspele zahvaljujući kontingencijskom faktoru veličine institucije, a različitom kombinacijom marketinškog miksa pronašle su put do korisnika svojih obrazovnih usluga, koje su kreirane po njihovoj meri. Da bi to bilo moguće sve tri organizacije su svoje resurse posvetile istraživanju, kako potreba i karakteristika svojih korisnika, tako i njihovog zadovoljstva obrazovnom uslugom. Istraživanja nisu ograničili na svoje korisnike, već se i konkurencija našla pod istraživačkom lupom. U tome im pomažu različite mogućnosti koje nude digitalni alati, kako po pitanju istraživanja, tako i po pitanju promotivnih aktivnosti i komunikacije sa ciljnim grupama. Ono što se u karakteristikama analiziranih obrazovnih brendova može zapaziti jeste da je u sva tri analizirana slučaja, od četiri karakteristike brenda vrednost najmanje izražena. Ovo nam govori da obrazovne organizacije upravo u okviru ove karakteristike imaju najviše prostora za napredak i razvoj. Vrednost bi zapravo trebala da bude „najandragoškija“ karakteristika obrazovnog brenda, jer je obrazovanje vrednost po sebi, a osim konkretnog razvijanja znanja, veštine ili stava, ona nudi i stil i način života, pogled na svet, smisao. Značajno je što su u sva tri slučaja nastavnici vodeći nosioci vrednosti. Istraživanje pokazuje da škole koje su dosegle status brenda pažljivo selektuju nastavne kadrove i da dosta ulažu u njihovo kontinuirano stručno usavršavanje. Škole su svesne da u očima korisnika, nastavnik je osoba koja predstavlja školu i koja opredmećuje obrazovnu uslugu. Nastavni kadar je toliko bitan u marketingu da su ga mnogi andragoški autori (Alibabić 2002; Miljković i Kovačević 2011; Miljković i Đurić 2017) uvrstili u marketinški miks kao peti elemenat. Sa druge strane, prevelika zavisnost obrazovne organizacije od nastavnika može biti opasnost po školu nisu retki slučajevi da nastavnici napuste školu i povedu većinu polaznika, jer se čini da će pre polaznici biti lojalni nastavniku nego ustanovi. To nam govori 
da škole moraju da vode računa o organizacionoj kulturi i klimi, i da učine sve kako bi njihovo nastavno osoblje bilo vrhunsko, ali i zadovoljno u isto vreme. Znamo da je svaka škola specifična i da je priča za sebe. Ali nakon istraživanja, ako bismo morali da sažmemo uspeh analiziranih obrazovnih organizacija i damo u tri reči „recept“ za kreiranje brenda u neformalnom obrazovanju, on bi sadržao: istraživanja, strategije koje su usmerene na ciljne grupe, a zasnovane na rezultatima istraživanja i kvalitetni nastavni kadar kao preduslov za uspeh u brendiranju organizacija neformalnog obrazovanja. 


\title{
Branding Foreign Language Schools as Organizations of Non-formal Adult Education
}

\begin{abstract}
A brand could be named as the marketing goal of any organization, including the educational one. The issue of brand in education is becoming more and more actual, but the current focus of the scientific community has remained mainly on branding higher education, while non-formal adult education organizations on this issue have been largely ignored. Therefore, we conducted research to determine whether users of nonformal education organizations perceive the educational service provider as a brand, as well as to identify which activities are carried out by non-formal education organizations to reach this level of connection with their users. The research used a combination of quantitative-qualitative research paradigm, with a multiple case study as a research model and a descriptive method as the dominant one. The research sample consists of managers and students of the analyzed foreign language schools. The results of the research indicate that non-formal education organizations in Serbia follow world trends and make efforts to achieve the status of an educational brand, that branding is not a uniform process, and that each organization and their strategies have certain specifics.
\end{abstract}

Keywords: brand in education, branding, non-formal education organizations, adult education, foreign language schools. 


\section{Literatura}

Alibabić, Š. 2002. Teorija organizacije obrazovanja odraslih. Beograd: IPA.

Aaker, J. 1997. Dimensions of brand personality. Journal of marketing research. 34, (3), str. 347-356.

Aaker, J. 1999. The malleable self: The role of self-expression in persuasion. Journal of marketing research. 36, (1), str. 45-57.

Aaker, D. 1991. Building strong brands. New York: The free press.

Đorđević-Boljanović, J. 2010. Organizaciona kultura kao faktor uticaja na efektivnost programa menadžmenta znanja. Singidunum review. 5 (2), str. 163-171.

Keller, K., Kotler, P. 2016. Marketing Management (15th Edition). London: Pearson.

Miljković, J. 2009. Marketing institucija visokog obrazovanja - studija slučaja. Andragoške studije. (2), str. 323-337.

Miljković, J. 2010. Professionalization of High Educational Institutions Marketing in Context of Crisis. In: Medić, S., Ebner, R., Popović, K. (eds.) (2010). Adult Education: The Response to Global Crisis Strengths and Chalenges of the Profession. Belgrade: DPA, IPA, EAEA, AES. pp. 207-220.

Miljković, J.; Kovačević, J. 2011. Elementi marketing miksa kao činioci visooobrazovne institucije. Andragoške studije. (1), str. 135-146.

Miljković, J.; Đuričić, M. 2017. Marketing miks kao činilac posećivanja profesionalnih pozorišnih predstava. Obrazovanje odraslih. (1-2), str. 53-74.

Ovesni, K. 2014. Posvećenost zaposlenih - element evaluacije i oslonac strategije unapređivanja kvaliteta. U: Knežić, B., Pejatović, A., Milošević, Z. (ured.) (2014). Modeli procenjivanja $i$ strategije unaprectivanja kvaliteta obrazovanja odraslih u Srbiji. Beograd: Institut za pedagogiju i andragogiju Filozofskog fakulteta u Beogradu, str. 155-175.

Rakita, B.; Mitić, S. 2010. Efekti transferisanja imidža kroz strategije kobrendiranja i ekstenzije brenda. Marketing. 41(2), str. 75-86.

Veljković, S. 2010. Brend menadžment u savremenim tržišnim uslovima. Beograd: Centar za izdavačku delatnost Ekonomskog fakulteta.

Veljković, S.; Đorđević, A. 2010. Vrednost brenda za potrošače i preduzeća. Marketing. 41(1), str. 3-16. 